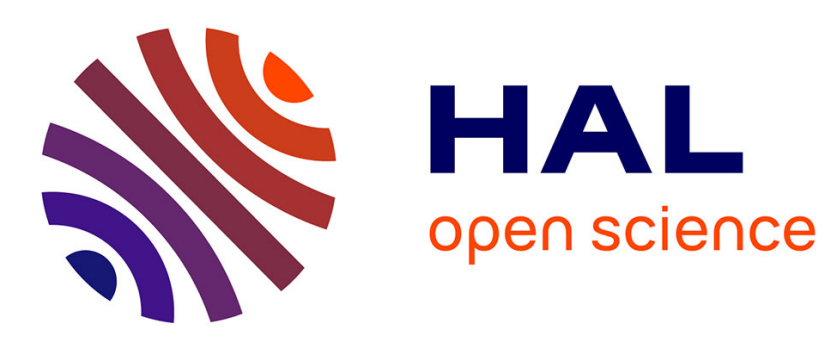

\title{
Tonal inflection in Mande languages: The cases of Bamana and Dan-Gw taa
}

Valentin Vydrin

\section{To cite this version:}

Valentin Vydrin. Tonal inflection in Mande languages: The cases of Bamana and Dan-Gw taa. Palancar, Enrique L., Léonard, Jean Léo. Tone and Inflection: New facts and new perspectives, De Gruyter, pp.83-105, 2016, 978-3-11-045275-4. halshs-01287458

\section{HAL Id: halshs-01287458 \\ https://shs.hal.science/halshs-01287458}

Submitted on 14 Mar 2016

HAL is a multi-disciplinary open access archive for the deposit and dissemination of scientific research documents, whether they are published or not. The documents may come from teaching and research institutions in France or abroad, or from public or private research centers.
L'archive ouverte pluridisciplinaire HAL, est destinée au dépôt et à la diffusion de documents scientifiques de niveau recherche, publiés ou non, émanant des établissements d'enseignement et de recherche français ou étrangers, des laboratoires publics ou privés. 


\title{
Tonal inflection in Mande languages: The cases of Bamana and Dan-Gwertaa
}

\author{
Valentin Vydrin
}

\section{Introduction}

Mande is a mid-range language family (its time depth ranges between 5000 and 6000 years) presumably belonging to the Niger-Congo macrofamily. It comprises more than 70 languages. Practically all Mande languages are tonal, therefore the Proto-Mande language most probably was tonal too. Tonal systems of the modern Mande languages are very diverse in the number of tones, in the complexity of rules conditioning the passage of tones from the underlying level to the surface, in the role grammatical tone and a number of tonal morphemes; for a survey (although outdated in some points) see (Vydrine 2004).

It would be too ambitious and too bulky to display here the tone inflections in all the Mande languages (or even those whose tonal systems are sufficiently well studied to date), so, I will limit myself by presenting tonal systems and tonal inflections in two languages of the family, Bamana (Bambara) and Dan (the Gwectaa dialect), belonging to different branches of the Mande family (35\% of cognates in M. Swadesh's 100-wordlist, which corresponds to more than 4000 years of independent existence). This presentation has a secondary task to show how different are these tonal systems, and therefore how risky it may be to refer to Mande tonal systems in general.

Bamana (also Bambara, Bamanankan, ISO 639-3 bam) is mainly spoken in the Republic of Mali by about 4,000,000 L1 speakers and up to 8,000,000 L2 speakers. Legally one of 13 "national languages" of Mali, Bamana is the major language of this country. It serves as lingua-franca everywhere, except for the North-Eastern part of the country. The official language of Mali is French, while "national languages" share among them mainly the oral sphere. However, it is also taught at a number of primary schools, there are several periodicals and an emergent literature in Bamana.

The Bamana language is represented by numerous local dialects displaying considerable divergences in what concerns the surface-level tonal and segmental realizations. ${ }^{1}$ These divergences may result in serious difficulties in mutual intelligibility (or its lacking) among speakers of different dialects, despite the fact that their grammars and vocabularies are similar. However, mutual understanding is ensured by the existence of a pandialectal koine, Standard Bamana stemming from the dialect of Bamako (the capital of Mali). The Bamana data analyzed in this paper belongs to Standard Bamana.

Dan (also Yakuba, Gio, ISO 639-3 dnj) counts about 1,600,000 speakers mainly in Côte d'Ivoire and Liberia; there are also compact areas of Dan in Guinea. ${ }^{2}$ It belongs to the Southern Mande group where it remains the biggest language, with relation to the number of speakers. Dan displays a considerable dialectal variation, which is typical of the languages of the forest zone: distant dialects may have up to 10\% (or slightly more) of divergent vocabulary in the Swadesh's 100 wordlist (Vydrin 2009a) and be mutually unintelligible. At least two Dan language norms are being established in Côte d'Ivoire: the Western Dan, based

\footnotetext{
${ }_{2}^{1}$ See http://www-01.sil.org/SILESR/2000/2000-003/Manding/Bamana.htm.

2 Cf. http://www-01.sil.org/SILESR/2000/2000-003/Dan-Tura-Mano_map.htm.
} 
on the Blo dialect, and the Eastern Dan, based on the Gwectaa dialect. In this paper, I concentrate on the analysis of the Eastern variety spoken in the Goueta sousprefecture of the Tonkpi Province of Côte d'Ivoire.

In section 2, I analyze the Bamana tonal system. Its main features are: two levels with a downdrift and downstep; low tone is the marked one; the tonal compactness rule regulates a merger of adjacent tonal domains within syntactic groups of certain types; a floating low tone plays a role of a definite/referential article.

In section 3, Dan Gwectaa tones are analyzed. This language has 5 level tones; context changes of tones are quasi-nonexistent; there are numerous grammatical tonal modifications; in the majority of cases, it is the extralow which appears as a grammatical tone; an interpretation of extralow as a default tone can be suggested.

\section{The tonal inflection in Bamana}

Bamana, with its two level tones, belongs to the languages with a minimal tonal inventory (cf. Hulst (2012) who suggests to analyze all two-level languages in terms of accent, rather than tone). Unlike the majority of two-level languages, in Bamana it is not the high, but the low tone that is marked. Bamana has a rather high rate of lexical minimal pairs distinguished only by tones: in a dictionary numbering 11,423 entries, 697 pairs have been found, i.e. 1393 words, or about $12,2 \%$ of the vocabulary, among these, there is an overwhelming majority of the most frequent words of the language, in particular many auxiliary words. Bamana is an isolating language with an extremely scanty segmental inflectional morphology, which prevents it from combining segmental and tonal elements of inflectional paradigms, for such paradigms are simply missing. Unlike many other Mande languages (including Dan, see below), Bamana has no tonal inflectional markers erasing lexical tones, - unless we consider as tonal inflection the tonal compactness (see 2.1; this solution seems to me unnecessary). The only tonal inflection available is the article (reference/definiteness marker) represented by a floating. The purpose of this division is to describe the tonal system of Bamana and the role of the tonal inflection.

\subsection{Basics of tonal phonology in Bamana.}

The tonal system of Bamana (and those of some closely related Manding varieties, very similar to Bamana) was subject of numerous publications, beginning with (Welmers 1949) and (Bird 1966). It was hotly debated since 1970s (Courtenay 1974, Creissels 1988, Creissels et Grégoire 1993, Creissels 2009, Dumestre 1987), and by now, it is more or less clear how this system works. ${ }^{3}$ In what follows, I will display its main features, which is necessary for the understanding of the Bamana tonal inflection.

As mentioned above, Bamana has a two-level tonal system. At the surface level, there is a great variability of pitches which is due to the phenomenon of downdrift and contextual tonal modifications described below.

\subsubsection{Tonally dominant and tonally recessive syllables, tonal domain.}

\footnotetext{
${ }^{3}$ There is also a formalist tradition of the study of Bamana tone represented mainly by American authors (Leben 2003, Weidmann et Rose 2006, Green 2010, ) intended to place the Bamana data into the framework of particular theories. In this paper, I am not going to discuss the formalist approaches to the Bamana tone.
} 
Syllables in Bamana fall into tonally dominant and tonally recessive. ${ }^{4}$ A tonally dominant syllable has a low or (by default) a high tone associated with it. A tonally recessive syllable inherits its tone from the preceding syllable; its surface tone can be also conditioned by the right context. A sequence consisting of a dominant syllable and the recessive syllables to its right (within a word or a tonally compact group), represents a tonal domain. ${ }^{5}$

$\begin{array}{llll}\mid \text { dùlokoto } & \rightarrow & \text { dùlòkòtò } & \text { 'produce blisters' } \\ \mid \text { éleke } & \rightarrow & \text { méléké }\end{array}$

Any word-initial syllable in a content word is dominant. All suffixes consist of recessive syllables. In most lexemes, it is the initial syllable only that is dominant, the others are recessive, so that the tonal domain coincides with the word. There are however some words that have non-initial dominant syllables. Such lexemes, which include more than one tonal domain, constitute 'minor tonal classes.' Among these, there are:

- prefixed and compound verbs:

$\begin{array}{llll}\text { |lá|sègin| } & \rightarrow & \text { lásègìn } & \text { 'return' } \\ \text { |kùnna|tìge| } & \rightarrow & \text { kùnnátìgè } & \text { 'relieve of shame' } \\ \text { |mà|fára| } & \rightarrow & \text { máfárá } & \text { 'separate' } \\ \text { |dála|téliya| } & \rightarrow & \text { dálátélíyá } & \text { 'force to speak quickly' }\end{array}$

- certain nouns (less than $10 \%$ of the vocabulary):

(3)

$\begin{array}{llll}\mid \text { jàn|kàmu| } & \rightarrow & \text { jănkàmù } & \text { 'black scorpion' } \\ \text { |fógon|fògon } & \rightarrow & \text { fógónfògòn } & \text { 'lung' } \\ \mid \text { bìla|kòro| } & \rightarrow & \text { billákòrò } & \text { 'uncircumcised boy' } \\ \mid \text { tál|sàlen| } & \rightarrow & \text { tásàlèn } & \text { 'kattle for ablutions' }\end{array}$

\subsubsection{Low tone markedness.}

Contrary to the general trend of tonal languages, it is the low tone that is marked in Bamana (Creissels et Grégoire 1993, Creissels 2009). ${ }^{6}$ As it is said above, the low tone associated with a dominant syllable spreads to the right up to the end of its domain (most often, to the end of the word, if there is no other low tone dominant syllable on its way):

$$
\text { |gè lenya } \quad \rightarrow \quad \text { gèlènyà } \quad \text { 'grow difficult' }
$$

A low tone spread to the right is curbed if it encounters another low tone associated with a syllable. In this case, a buffer high tone is necessarily inserted between the two low tones.

\footnotetext{
${ }^{4}$ Cf. Eric Campbell's paper on Zenzontepec Chatino (this volume) where tone bearing units similar (although not identical!) to the Bamana "tonally recessive" ones are analysed as "no tone morae". A crucial difference between the Zenzontepec Chatino "no tone morae" and the Bamana "tonally recessive syllables" lies in the fact that the former carries a default low tone in a "neutral" context which is ousted by the marked mid and high tones in certain contexts according to the predefined set of rules, while in Bamana, the "recessive syllables" have no tone of their own, their tonality always depends completely on the left or right context. Alternatively, the "recessive syllables" in Bamana could be termed as "no tone syllables" too.

${ }^{5}$ The vowels of tonally dominant syllables are underlined. A vertical bar subdivides a word into domains. The acute accent designates a high tone, and the grave accent stands for a low tone.

${ }^{6}$ Both publications deal with the Kita Maninka, however, the analysis is relevant for Bamana as well. I am not going to reproduce here Creissel's argumentation in favour of the low tone markedness.
} 
The buffer high tone is associated with the final segment of the first low tone domain: its final mora (if the domain is equal to one syllable), its final syllable (if the domain includes more than one syllable), its final foot (if the domain includes two feet or more).

In (5a), the first domain consists of only one syllable $m a$, and the buffer high tone is assigned to the second mora of the first syllable, so that the syllable acquires a rising tone. In (5b), the first domain covers two syllables, kun-na, and the buffer high tone is assigned to its final syllable. If a dominant syllable is not assigned a low ton, it acquires, by default, a high tone which spreads to all the subsequent recessive syllables of the domain, whatever may be the tone of the following domain (in $5 \mathrm{c}$-d, this process can be also regarded as an insertion of a buffer high tone at the end of the high-tone domain, the result is the same).
a. |mà $\mid$ dòn $\mid \rightarrow$ mădòn
'approach'
b. |kùnna|sìri $\rightarrow$ kùnnásirì
'be ashamed'
c. |bólo|bán $\mid \rightarrow$ bólóbán
'get ruined'
d. |bólo|kò $\mid \rightarrow$ bólókò
'pass initiation'

It can be therefore said that in Bamana, two adjacent low tone domains are separated by a high tone. ${ }^{7}$

\subsubsection{Tonal compactness.}

Certain types of syntactic constructions are subject to the rule of 'tonal compactness'. In a tonally compact construction, all the domains, except the initial one, are eliminated, and the initial domain extends up to the right boundary of the construction. If the resulting domain carries the low tone and is followed by another low-tone element, its final component is assigned a high tone. ${ }^{8}$ The following constructions are tonally compact:

- the attributive construction, "noun + simple adjective": 9

(6) |mìsi| 'cow' + |bìlen| 'red'+`ART

|só| 'house' + |bìlen| 'red’+`ART

$$
\begin{array}{ll}
\rightarrow \text { misi bilén-' } & \text { 'red cow' } \\
\rightarrow \text { só bilén-' } & \text { 'red house' }
\end{array}
$$

The entire sequence represents one tonal domain, so that its final dissyllabic segment, bilen, followed by a floating low tone of the article (see below), is assigned a buffer high tone (if the tonal compactness rule were not applied, the tonal contours would be *misi bilén- , *só bilén- ');

- the determinative construction, "dependent noun + head noun":

(7) a. |mù̀so| 'woman' + |sèn| 'foot/leg'+'ART $\rightarrow$ mùsò sén-' 'feminine foot/leg'

b. |kámalen| 'young man' + |sènn| 'foot/leg'+`ART $\rightarrow$ kámálén sén-' 'young man foot/leg'

\footnotetext{
${ }^{7}$ There are in fact some exceptions: the infinitive marker kà and the 3SG pronoun $a ̀$ always appear with low tone, without any rising, even when followed by another low-tone word.

8 Tonal compactness in Manding resembles, at least externally, the tonal transformation in Shanghai, as described in (Yip 2007, 242).

${ }_{9}^{9}$ More precisely, focalized adjectives derived from qualitative verbs by the means of the suffix -man also form tonally compact groups with their head nouns: $\mid$ só $\mid$ 'hous' + |fin-man $\mid$ 'black' $\rightarrow$ só finmán 'the house (which is) black'. Adjectives derived with other suffixes behave as tonally autonomous.
} 
Note that without the tonal compactness rule, the tonal contour would be *mùsó sèn-， *kámálén sěn-`.

- the preverbial construction, "preverbal adverb + verb":

(8)

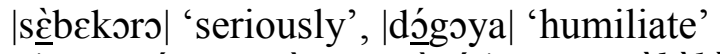

$$
\begin{aligned}
& \text { à yé à mùsó-’ sèbèkj̀rò dògj̀yà. } \\
& \text { 3SG PFV.TR 3SG woman-ART seriously humiliate } \\
& \text { 'He seriously humiliated his wife.' (rather than *... sc̀bèkj̀rò dógóyá ) }
\end{aligned}
$$

\subsubsection{Downdrift.}

The downdrift in Bamana follows a typical model: the range of rising in the sequence "Low High" is roughly a half of the range of lowering in the sequence "High - Low". As a result, a high tone at the end of a sentence may be realized at the same level as a sentence-initial low tone, or even below that level: ${ }^{10}$

(9)

$\begin{array}{lllll}\text { A } & \text { té } & \text { sigi } & \text { só. } & \text { 'He does not stay at home.' } \\ 3 \mathrm{SG} & \text { IPFV.NEG } & \text { sit } & \text { home } & \end{array}$

\subsection{Tonal inflection in Bamana: the floating low tone as the definite/referential article.}

The only tonal inflection in Bamana is a definite (or referential) article. It is realized primarily on the tonal domain following the NP with which the article is associated: if the following domain carries a high tone, this high tone becomes downstepped. This phenomenon is usually described by postulating that the definite/referential NP is followed by a floating low tone, which interacts with the tone of the following domain.

It should be also noted that the floating low tone is suffixed to a noun or to an attribute (in other words, to the rightmost element of a noun phrase of the structure $\mathrm{N}+\mathrm{Atr}$ ). ${ }^{11}$ Despite the fact that it has no segmental support, it represents a tonal domain of its own. See example (10), where the high tone of $t \varepsilon$ goes down a notch in relation to the high tone of jégé. ${ }^{12}$

\footnotetext{
${ }^{10}$ This is the way the Bamana downdrift is most often represented in grammars. In fact, the reality is more complicated: as a rule, the phrase-initial low tone is realized very low, and the subsequent high tone rises very high; then follows a sharp drop. As a result, the first high tone in a sentence becomes very proeminent, while all subsequent tonal fluctuations are considerably less significant in amplitude. However, for the purposes of this paper, these peculiarities (most probably, of intonative nature) are of no crucial importance, and we can abstract ourselves from these details.

${ }^{11}$ In some theoretical approaches, the term "article" is applied only to syntactic words, and not to affixes. However, other approaches are possible as well, where affixes can be regarded as articles too. There is a long tradition of treating inflectional affixes as articles in such languages as Swedish, Rumanian, Bulgarian, Literary Arabic, and many others. In Manding languages, the tonal (in Bamana, Maninka, Jula) or segmental (in Mandinka, Xasonka, Marka-Dafing) grammatical morpheme of definiteness is most often referred to as "article", although sometimes, descriptive definitions are used (e.g., "marqueur de détermination nominale" , Creissels and Sambou, 2013:17). In this paper, I will keep the term "article", in line with the predominant Mandeist tradition.

${ }_{12}$ The dotted line shows an underlying contour of the floating low tone.
} 
(10)

Jع́gété yàn.

fish-ART
NEG.be here
'The fish is not here.'

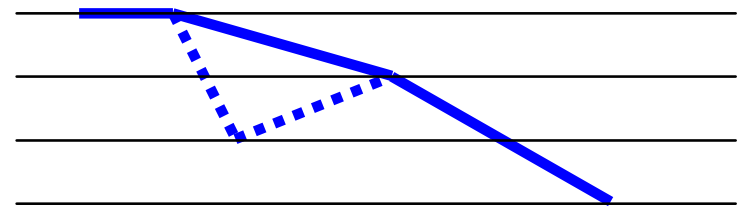

If the domain preceding the tonal article is low-tonal, a buffer high tone is necessarily inserted at its end, just before the floating low tone (following the rule of "low tone markedness"), see (11).

(11)

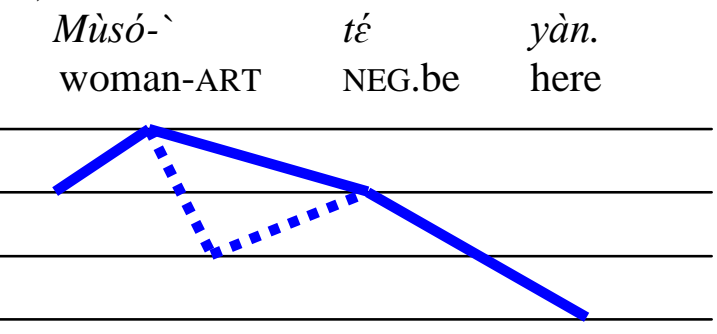

'The woman is not here.'

In the absence of a floating low tone, the tonal contour of the phrase is very distinctly different, cf. (12).

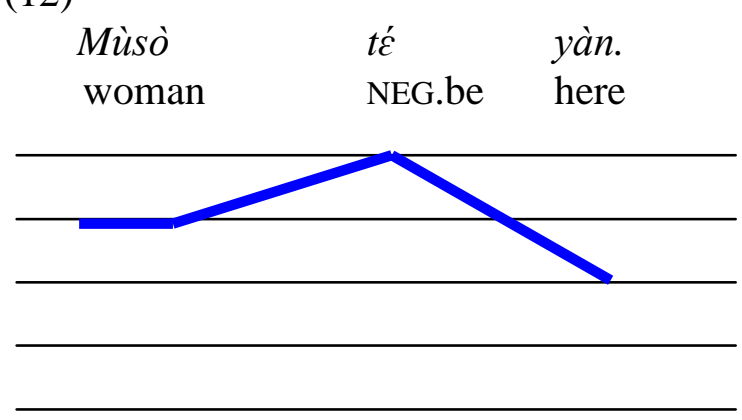

The floating low tone is neutralized if the following word begins with a low tone. In this context, presence of absence of the tonal article cannot be observed at the surface level. Therefore, sentences (13.a), where fàli 'donkey' carries an article, and (13.b), where it has no article, are homonymous: 


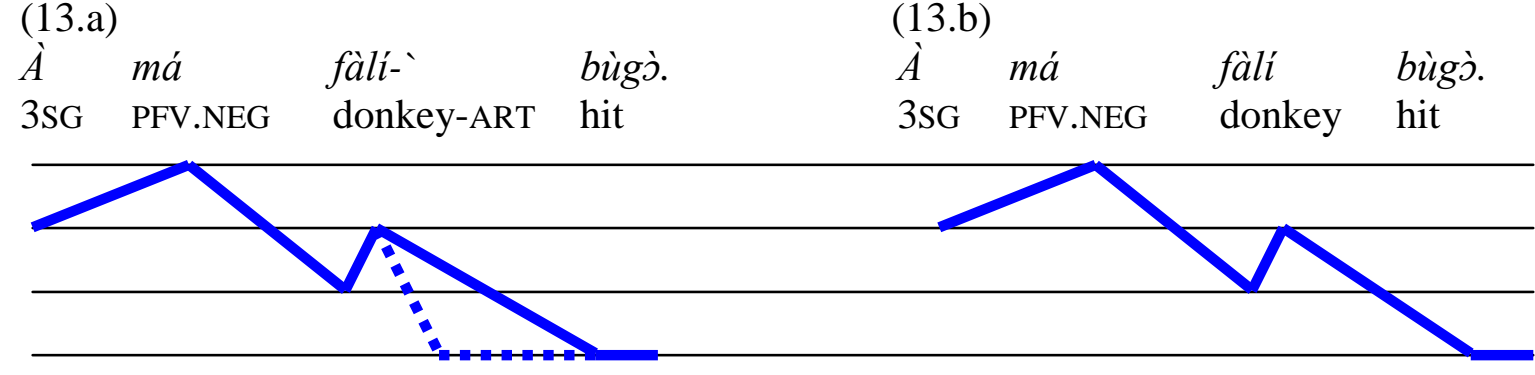

'He didn't hit the donkey.'

'He didn’t hit donkeys / a donkey.'

In the texts, nouns appear most frequently with the article. Here are some contexts where forms with and without the article can be differentiated:

- under negation (11 and 12; 13a and 13b) or under question;

- a determinative (14.a) and a possessive inalienable (14.b) noun constructions:

(14.a)
mùsò sén-`
woman foot/leg-ART

'a/the feminine foot/leg' (14.b)
mùsó-` sěn-
woman-ART foot/leg-ART
'a/the woman's foot/leg.'

- evidential opposition of a non-firsthand (non-visual) information (15.a) vs. firsthand (visual) information (15.b) in the progressive:
a. $\quad{ }^{\prime}$
dógóké-
bé kàlàn-nà
Fránsí.
1SG younger.brother-ART COP learn-NONVIS France
'My younger brother makes his studies in France.' (and I'm in Mali)
b. Ń dógóké-`
bé kàlán-`
ná.
1SG younger.brother-ART COP learning-ART PP
'My younger brother is studying.' (and here is he with a book)

In the construction of non-firsthand information (15.a), the verb appears with the suffix -la (the -na form is used when the preceding vowel is nasal) which is tonally recessive (it inherits its tone from the verb). The firsthand information construction 15.b) is technically non-verbal: the verb is nominalized and appears with the tonal article, it is followed by the locative postposition ná which carries a downstepped high tone. ${ }^{13}$

ORIGIN: the tonal article in Bamana comes back to the segmental article $*_{-} o$. This form is still attested in numerous varieties spoken on the geographic periphery of the Manding area: Mandinka, Xasonka, Worodugukan, Marka-Dafin, some Kagoro dialects. Some traces of the segmental article - $o$ can be found even in some eastern dialects of Bamana, e.g., the dialect of Bore (Давыдов 2011). In its turn, * $\dot{o}$ comes back to an anaphoric pronoun / remote demonstrative determinant $* \dot{o} \sim * w \grave{o}$ (its reflex in modern Bamana is $\dot{o}$ ).

\footnotetext{
${ }^{13}$ This construction seems to be the only one in Bamana where this -la-form can be used. However, in closely related Manding varieties, such as Maninka of Kita (Creissels 2009), Mandinka (Creissels et Sambou 2013, 125131), Standard Maninka of Guinea, an analogous form is much more current and appears in various contexts; it can be interpreted in those varieties as an infinitive. The suffix -la goes back to the locative postposition -lá, the same as in the "visual construction" (21b). Therefore, the difference between both constructions is not fortuitous; in fact, they represent one and the same construction at different stages of grammaticalization.
} 


\section{The tonal inflection in Dan-Gwertaa.}

The tonal system of Dan-Gwectaa is radically different from that of Bamana: a great number of contrastive tones; almost non-existent contextual modifications of tones; no differentiation into dominant and recessive syllables; a considerable number of inflectional tonal morphemes in all major segments of grammar: verb, noun, auxiliaries.

\subsection{Basics of tonal phonology in Dan.}

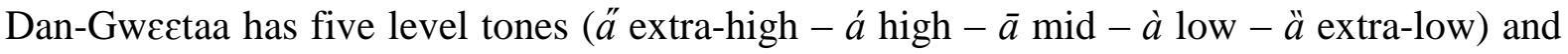
three modulated tones (all are falling: $\ddot{a}$ extra-high-falling $-\hat{a}$ high-falling $-a \square$ mid-falling). In the tonological studies, existence of true five-level tonal systems are often treated with certain distrust, ${ }^{14}$ therefore, I am illustrating the tone contrasts in table 1.

Table 1. Minimal series demonstrating contrast of five level tones in Dan-Gwectaa

\begin{tabular}{|c|c|c|c|c|c|c|}
\hline \multicolumn{2}{|l|}{ Extra-High } & \multirow{3}{*}{$\begin{array}{l}d_{\varepsilon}^{\prime \prime} \\
\text { 'leaves' } \\
d_{\varepsilon}^{\prime} \\
\text { 'other' }\end{array}$} & & \multirow{6}{*}{$\begin{array}{l}g b \ddot{a} \text { ' } \\
\text { 'foot, leg' } \\
\text { gbāa } \\
\text { 'wing', } \\
\text { gbàa } \\
\text { 'ceiling' } \\
g b \ddot{a} \\
\text { 'go in' (sharp object) } \\
\text { gbâa } \\
\text { 'uproar' }\end{array}$} & \multirow{5}{*}{$\begin{array}{l}\text { käă } \\
\text { 'scabies' } \\
\text { káá } \\
\text { 2PL NEG, PRESTV } \\
\text { kāā } \\
\text { 2PL PROSP } \\
\text { kàà } \\
\text { 'scratch' } \\
\text { kää } \\
\text { 'reed' }\end{array}$} & \multirow{6}{*}{$\begin{array}{l}y \ddot{\prime} \\
\text { 'yams (sp.)' } \\
y a ́ \\
\text { 1PL.EXCL PRF } \\
y \bar{a} \\
\text { 'here' } \\
y \grave{a} \sim y \ddot{a} \\
\text { 3SG of PRF } \\
y \ddot{a} \\
\text { 'sit down' } \\
y \hat{a} \\
\text { 'badly' }\end{array}$} \\
\hline High & & & \multirow{4}{*}{$\begin{array}{l}\text { gટ́ } \\
\text { 'miss sb.' } \\
g \overline{2} \\
\text { 'venerable' } \\
g \grave{2} \\
\text { 'husband' } \\
\text { gב̃ } \\
\text { 'grass shed' }\end{array}$} & & & \\
\hline Mid & $\begin{array}{l}d \bar{l} \\
\text { 'taste' }\end{array}$ & & & & & \\
\hline Low & \multirow{3}{*}{$\begin{array}{l}d \underset{i}{i} \\
\text { 'disappointment' }\end{array}$} & $\begin{array}{l}d \hat{\varepsilon} \\
\text { 'how many?' }\end{array}$ & & & & \\
\hline Extra-Low & & $\begin{array}{l}d \ddot{\varepsilon} \\
\text { 'call' }\end{array}$ & & & & \\
\hline High-Falling & & & & & & \\
\hline Mid-Falling & $\begin{array}{l}d i \square \\
\text { 'hunger' }\end{array}$ & & & & & \\
\hline
\end{tabular}

Modulated lexical tones, especially Extrahigh-Falling (tīitïdè 'extremely black', zīızidè 'extremely ancient') and Mid-Falling are rare. Because of their rarity, the phonological status of lexical modulated tones (single tones or combinations of level tones) is difficult to be determined. An argument in favour of a bi-tonemic interpretation of the modulated tones is the fact that falling tones in Dan-Gwectaa also result from combination with an extralow tonal suffix which serves as the infinitive marker (see 3.2).

The domain of a tone is the syllable. Another important rhythmic unit in Dan is the metric foot (cf. in particular (Vydrin 2010a)): there are numerous restrictions on combinations of tones within this unit (see 3.1.2). There are in Dan light feet (V, CV), heavy feet (CVV, CVy, CVVV, CVVy, ClVy, ClVV) and extraheavy feet (CVVV, CVVy). Contextual changes of tones are very few (and they will not be discussed in this paper).

\footnotetext{
${ }^{14}$ Cf. for example in (Yip 2007, 231): "it is possible to contrast up to four $<\ldots>$ and probably five $<\ldots>$ different level tones".
} 


\subsection{Is there a neutral tone in Dan-Gweetaa?}

In tonological studies, one can find statements as the following one: "In a three-tone language, neutralization of tonal contrasts by tone deletion will be to M" (Odden 1996, 21). Let us see if the same trend is valid in a five-level language. In Dan-Gwectaa, there seems to be no clear cases of tonal neutralization. However, the following facts can be considered in this relation:

1) In heavy feet, there are rather strict restrictions on tonal combinations:

- all combinations of identical initial and final tones are allowed (cf. the kaa series in the table 1);

- all combinations with the final extralow tone are possible: flëë 'kernel of a nut', fáä 'hat', $d \bar{\gamma} \bar{y}$ 'citrus fruit', kèë 'after' (the latter pattern, Low-Extralow, is relatively rare);

- combinations "mid-high" and "mid-extrahigh" are allowed, although both are much less frequent than those with final extralow tone: $s \bar{\sim} \bar{y}$ 'star', yēe" 'cotton'.

Other tonal combinations are extremely rare (Low-Extrahigh: wè̀" Mid-Low: sùa 'falsehood'; etc.). The combinations of tones in the feet are represented in the Table 2.

Table 2. Combinations of tones in the feet in Dan-Gwectaa.

2 EL $\quad$ L $\quad M \quad H \quad$ EH

1

\begin{tabular}{l|l|l|l|l|l|}
\cline { 3 - 6 } $\mathrm{EH}$ & + & -- & -- & -- & + \\
\cline { 2 - 6 } $\mathrm{H}$ & + & -- & -- & + & -- \\
\cline { 2 - 6 } $\mathrm{M}$ & + & $($ rare $)$ & + & + & + \\
\cline { 2 - 6 } $\mathrm{L}$ & + & + & -- & -- & (rare) \\
\cline { 2 - 6 } $\mathrm{EL}$ & + & -- & -- & -- & -- \\
\cline { 2 - 6 } & & & & &
\end{tabular}

The three modulated tones in Dan-Gwectaa (mentioned in 3.1.1) reproduce the most frequent tonal patters of the heavy feet; all end in extralow tone. An extraheavy feet, as a rule,

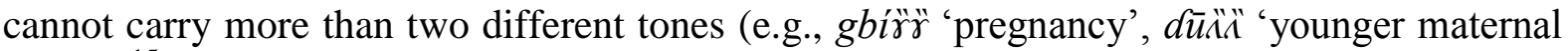
uncle'). ${ }^{15}$ Their tonal patterns are the same as those of the heavy feet.

2) Among the tonal morphemes described below, the most grammaticalized ones (and, at the same time, those whose origins are the most difficult to trace back) are those of the neutral aspect, the conjoint form of the verb, the infinitive, the nominalization, and the izaphet. Of these, three are represented by the extralow tone, and one (the tonal modification of the conjoint form) is represented by a tonal lowering (to the extralow or low, rarely to the mid tone), which can also be interpreted as a result of amalgamation of the tone of the stem with an extralow-tone morpheme.

With all necessary reservations, one can suggest the interpretation of the extralow tone in Dan Gwectaa as a default one. If so, one could speak of oppositions of the lexical tones (in their diversity) to the uniforme (extralow) grammatical tones, and that of the diverse footinitial tones (a strong position) to the final tone (either the same as the initial, or extralow).

\footnotetext{
${ }^{15}$ The only exception seems to be a Manding borrowing gbàúü 'kitchen' (from Jula gbà-búgú ).
} 


\subsection{Tone as an exponent of inflection. ${ }^{16}$}

\subsubsection{Infinitive}

The infinitive is marked by a syllable-final tonal modulation of the verbal stem. ${ }^{17} \mathrm{Cf} .(16 \mathrm{a})$, where the verb $d \bar{a}$ 'save' is used in the construction of perfect with its lexical tone, and (16b) where it appears in the infinitive form (in both tomograms, the verb $d \bar{a}$ is indicated with cursors; the tonal drop at the end of the verb is clearly visible in (16b)):
(16.a) B⿺廴́ $\dot{\gamma}$
$d \dot{\gamma}^{\prime}, \quad y \ddot{\gamma}$
$\bar{\gamma} \quad d \ddot{e} d \bar{a} !$
humanlEMPH REL.3SG.JNT be 3SG.OPT REFL.SG self save
'Every man for himself!' (Sauve qui peut!)

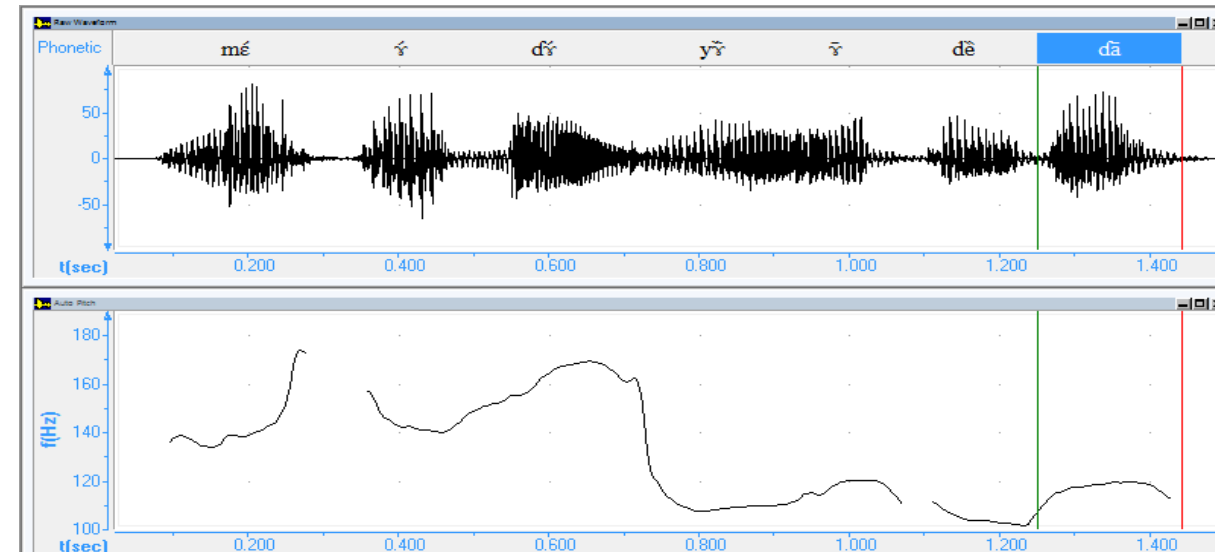

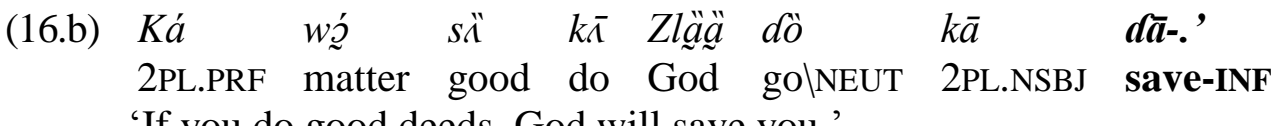

'If you do good deeds, God will save you.'

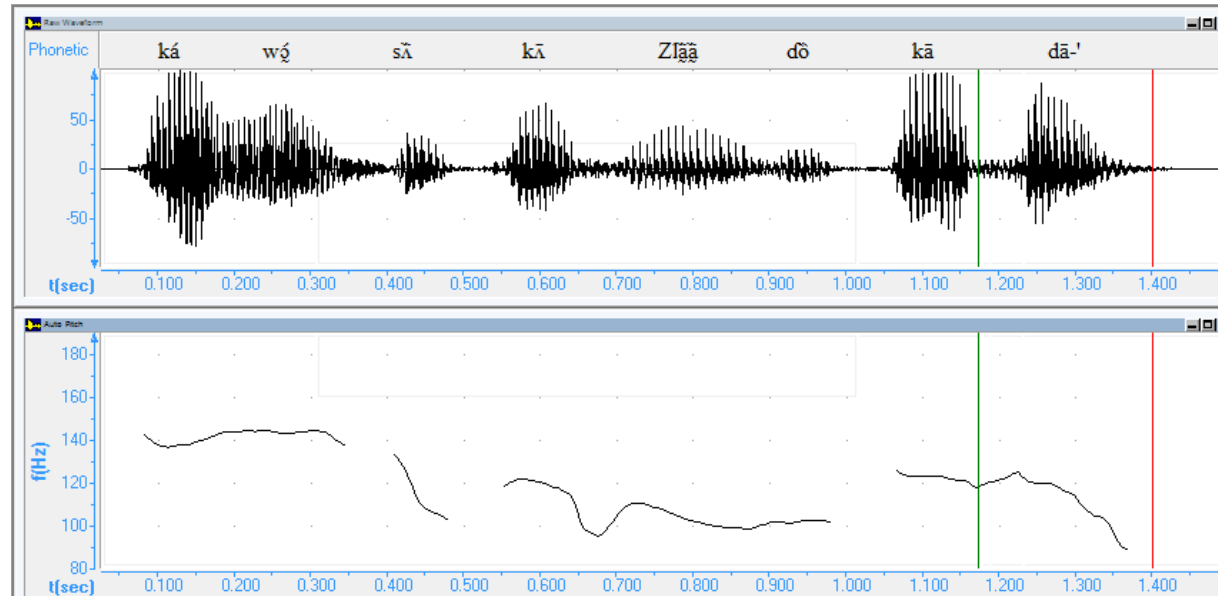

ORIGIN: The infinitive marker seems to come back to the same $* 6 \ddot{a}$ or $* 6 \ddot{a}$ postposition as the neutral aspect marker (see below); it represents another cycle of grammaticalization of this postposition (Vydrin 2012).

\footnotetext{
${ }^{16}$ Tone also serves in Dan-Gwectaa to express degrees of intensity of adjectives (often in combination with

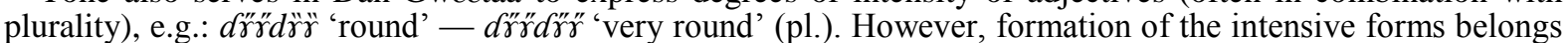
rather to the derivation than to inflection, so, it will not be analyzed here.

${ }^{17}$ Designated here by an apostrpohe.
} 


\subsubsection{Inflections of pronominal predicative markers (or auxiliaries).}

The basic word order in a verbal phrase is (S) AUX - (DO) - V, where $\mathrm{S}$ is a subject (optional), AUX is an auxiliary word whose root expresses person and number, and the inflection expresses TAM and polarity; DO is a direct object which is obligatory in the transitive constructions and impossible in intransitive ones; $\mathrm{V}$ is a verbal predicate. The inflections within AUXs are very often expressed either by tones only, or simultaneously by tonal and segmental modifications of the stems, cf. table $3 .{ }^{18}$

Table 3. Pronominal predicative makers in Dan-Gwectaa.

\begin{tabular}{|c|c|c|c|c|c|c|c|c|c|c|}
\hline & \multicolumn{4}{|c|}{ Singular } & \multirow{2}{*}{$\begin{array}{l}\text { Dual } \\
\text { INCL }\end{array}$} & \multicolumn{5}{|c|}{ Plural } \\
\hline & 1 & 2 & 3 & Log. & & 1.EXCL & 1.INCL & 2 & 3 & Log. \\
\hline Existential & $\bar{a}$ & $\bar{\imath} / \bar{u}$ & $y \ddot{\gamma} / y \grave{r}$ & $\bar{\gamma}$ & $k \bar{o}$ & $y \bar{l}$ & $k w \bar{a}$ & $k \bar{a}$ & $w \ddot{~}$ & $w \bar{o}$ \\
\hline Conjoint & $\dot{a}$ & $i / u^{\prime}$ & $\emptyset / \gamma^{\prime} / y \dot{\gamma}^{\prime}$ & $\dot{r}$ & $k o ́$ & $y i$ & $k w a ́$ & $k a ́$ & wó & $w o ́$ \\
\hline \multirow{2}{*}{$\begin{array}{l}\text { Optative } \\
\text { Perfect }\end{array}$} & $\dot{a}$ & $i / u^{\prime}$ & $\emptyset / y \ddot{\gamma}$ & $\ddot{\gamma}$ & $k o ́$ & $y i$ & $k w a ́$ & $k a ́$ & $w o ̈$ & wö \\
\hline & $6 \ddot{a}$ & $6 a ́$ & yà/yä & $y a ́$ & $k o ́$ & yá & $k w a ́$ & $k a ́$ & $w \grave{a} / w a ̈$ & $w a ́$ \\
\hline Prohibitive & $6 \underline{a}$ & $6 a ́$ & $y a ́$ & - & kó & yá & $k w a ́$ & $k a ́$ & $w a ́$ & - \\
\hline Prospective & $6 \bar{a} \bar{a}$ & $6 \bar{\imath}$ & $y \bar{\gamma} \bar{\gamma}$ & - & $k \bar{o} \bar{o}$ & $y \bar{l}$ & $k w \bar{a} \bar{a}$ & $k \bar{a} \bar{a}$ & $w \bar{o} \bar{o}$ & - \\
\hline \multirow{4}{*}{$\begin{array}{l}\text { Presumptive } \\
\text { Neg. Imperfective } \\
\text { Neg. Perfective } \\
\text { Imperative }\end{array}$} & $6 \bar{a} \bar{a}$ & $6 \bar{a} a ̈$ & $y \bar{a} \ddot{a}$ & - & $k \bar{o} o ̈$ & $y \bar{a} \ddot{a}$ & $k w \bar{a} a \ddot{~}$ & $k \bar{a} a ̈$ & $w \bar{a} a ̈$ & - \\
\hline & $6 \underset{\sim}{b a ́ a}$ & báá & yáá & - & kóó & yáá & $k w a ́ a ́$ & $k a ́ a ́$ & wáá & - \\
\hline & biij & bii & yií & - & kóó & yií & kwii & kii & wií & - \\
\hline & - & $\varnothing / 6 \ddot{\gamma}$ & - & - & $k \ddot{o}$ & - & $k w a ̈$ & $k \ddot{a}$ & - & - \\
\hline
\end{tabular}

Existential, optative and conjoint sets differ only in tones; the same is true for the sets of the perfect and prohibitive, presumptive and negative imperfective. Diachronically, these sets result from fusion of subject pronouns with auxiliaries.

\subsubsection{Neutral aspect marker on the verb}

In modern Dan-Gwectaa, the neutral aspect is marked on the verbal root (which usually coincides with a metric foot) by an extra-low tone (replacing the lexical tones). ${ }^{19} \mathrm{Cf}$. (17a), where the verb we 'speak' appears with its lexical tone, and (17b) where it is used in the construction of neutral aspect:

(17.a) Yà wë $\bar{\gamma} \quad$ yüúd

3SG.PRF speak REFL.SG nose.LOC

'He has snuffled.'

(17.b) $Y \grave{r}$

wë $\quad \bar{r} \quad y \bar{u} \bar{u} d \bar{r}$.

3SG.EXIST speaklNEUT REFL.SG nose.LOC

'He snuffles.'

ORIGIN: The neutral aspect extra-low tone morpheme comes back to a locative postposition $* 6 \ddot{a}$ or $* b a ̈$ which first grammaticalized into an imperfective marker (via the stage of an infinitive or supin marker). In more detail, see (Vydrin 2012).

\footnotetext{
${ }^{18}$ For reasons of space, I cannot delve here into detailed description of grammatical semantics and functions of the predicative pronominal markers.

${ }^{19}$ For the details on the neutral aspect in Dan-Gwettaa see (Vydrin 2010b).
} 


\subsubsection{Conjoint status marker}

The "conjoint" (dependent) status of the verbal construction is marked by the tone lowering of the root morpheme (a metric foot) of a verb; the conjoint form of a verb is necessarily preceded by a predicative marker of the conjoint set (see above). This marker appears in dependent clauses, after a focalized NP (18b), in consecutive constructions, and in some other contexts. Cf. (18a), where the verb appears with its lexical tone:

(28.a) Gwï yà glūūūy.

stone 3SG.PRF roll

'The/a stone has rolled.'

(28.b) Gwü dị̀ $\dot{r} \quad$ glüüü.

stone FOC REL.3SG.COJNT rolllCOJNT

'It is a stone that is rolling.'

The pattern of the lowering depends on the lexical tone of the verb and on the metric foot structure. There is no single rule for all the verbs; there are rather several classes of verbs, each of them follows a rule of its own, e.g. in (19), (altogether, 13 models of tonal change are available).

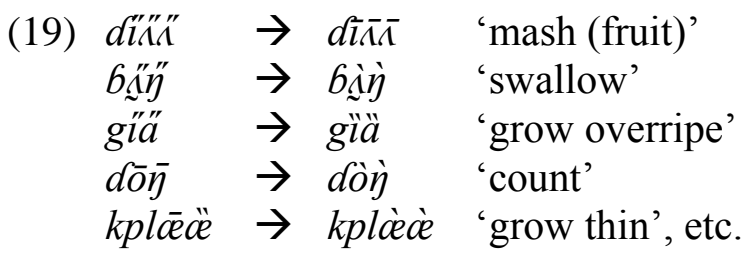

ORIGIN: The tonal lowering (the marker of the conjoint status marker) may originate in a segmental suffix whose form cannot be reconstructed at the present state of our knowledge.

\subsubsection{Tone as an exponent of the izaphet marker $^{20}$}

In certain types of inalienable possessive nominal constructions, the extra-low tone (replacing lexical tones) on the root morpheme of a noun is used as the izaphet marker. Cf.

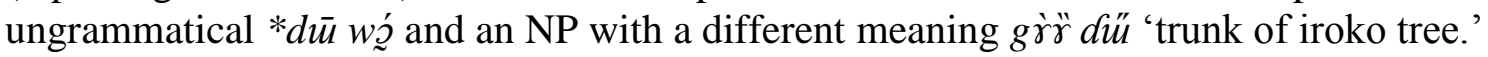

(20) $d \bar{u} \quad w \ddot{z}$

magic matter\ZZF

'sorcery' (wó $\rightarrow$ wö)

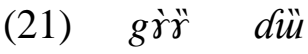

iroko treelIZF

'iroko tree' (diú $\rightarrow$ diü)

Application or non-application of this tonal inflection is influenced by several factors which look rather as tendencies than as rules (in fact, they are not yet utterly clear):

- words with generic meanings are more inclined to carry the izaphet marker: $b \bar{\varepsilon}$ 'human being', dè 'woman', bü 'wilderness', bláà 'farm, field', dīāȳ 'talk, speech', dü 'tree'

${ }^{20}$ Izaphet is a head marking in nominal constructions. 


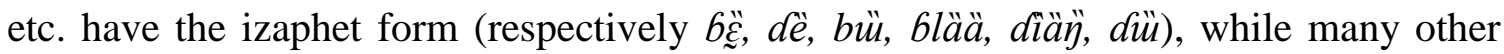
nouns with more specific meanings do not;

- if the two nouns in the construction are in the PART - WHOLE relation, the izaphet marking is absent $(22 a, 23 a)$. If the relation can be described as "the first noun equals the second one", the izaphet marker is present $(22 b, 23 b)$ :

(22) a. bāā dï 'cassava stem',

b. bāā dïu 'cassava plant' (dï 'tree')

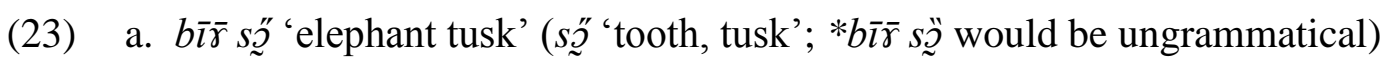

b. bīs wü 'elephant's carcass', 'elephant's body' ( $w \bar{u}$ 'meat');

- application or non-application of the izaphet tonal morpheme may depend on rhythmic factors, such as position of the construction in the sentence.

Most probably, the izaphet (extra-)low-tone morpheme should be reconstructed already for the Proto-South-Mande level: similar tonal morphemes are attested in other varieties of Dan (Макеева 2012), in Mano and Guro. Related phenomena are also found in some Southwestern Mande languages and in Susu (Green \& Anderson \& Obeng 2013), which can be viewed as an argument in favour of even more ancient origin of this tonal inflection.

\subsubsection{Nominalization}

When a verb is nominalized together with its indirect object or cicumstant (which keeps its post-verbal position), the lexical tone of the verb is substituted by an extralow tone which can be regarded as a nominalization marker:

$$
\begin{aligned}
& y i \text { tö ká bīr̈gā } \\
& \text { water drawlNMLZ with creeper } \\
& \text { 'rope for drawing water' (cf. tó 'draw (water)') }
\end{aligned}
$$

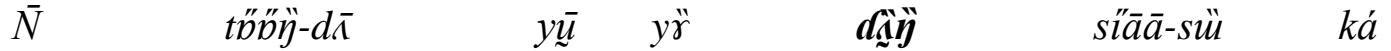

$$
\begin{aligned}
& \text { 1SG.NSUBJ namesake-father nose 3SG.EXIST STICKINMLZ land.sub-ger with } \\
& \text { 'My friend has a flat nose' (lit. "My friend's nose is stuck to the earth”, cf. dì̀ 'stick'). }
\end{aligned}
$$

ORIGIN: This tonal infection can be probably reconstructed for the proto-language of the Mano-Dan-Tura subgroup: at least in one other language of the subgroup, Mano, a low-tone morpheme is available whose semantics and usage is exactly the same as the nominalization tonal morpheme in Dan-Gwectaa (Khachaturyan 2014).

\subsubsection{Case in locative nouns.}

There is a subclass of nouns, the so-called locative nouns, which have developed a declension system comprising six cases: common, locative, inessive, subessive, adessive, comitative. The declension patterns are highly irregular. Most nouns have only two cases (usually, the common and the locative case). Not a single locative noun has all six case forms. Different cases are formed by using a whole number of formal means: suffixes, final vowel copying, vowel modification, tonal modifications. The latter case is illustrated by examples (26-29), 
where cases are expressed by tones: mid or extrahigh for the comitative case $(26,28)$, extralow for the subessive case $(27,29)$.

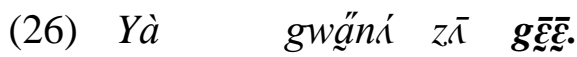

3SG.PRF cat hit foot/leg.COM

'He has kicked a cat.'

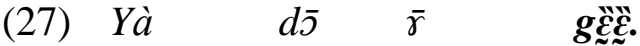

3SG.PRF stand REFL.SG foot/leg.SUB

'He has got up.'

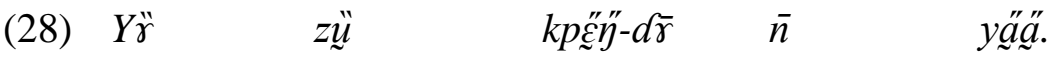

3SG.EXIST reachlNEUT ouside-LOC 1SG.NSUBJ eye.COM

'He has got out in my presence.'

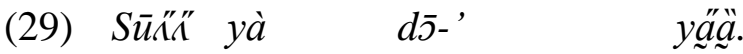

sty 3sG.PRF put-3SG.NSUBJ eye.SUB

'He has got a sty on his eye.'

The locative nouns are not very numerous: in my Dan-Gwectaa dictionary (version from June 2014 containing 2775 lexemes), there were 53 of them (without toponyms). There are five locative nouns that differentiate case forms by tones only, see table 4.

Table 4. Locative nouns with case forms differentiated only by tones

\begin{tabular}{|c|c|c|c|c|c|}
\hline COMMON & LOCATIVE & INESSIVE & SuBESSIVE & ADESSIVE & Comitative \\
\hline 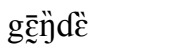 & $g \bar{\varepsilon} \bar{y} d \bar{r}$ & & gęֶّ & & $\mathrm{g} \overline{\mathrm{g}} \overline{\mathrm{q}} \overline{\mathrm{g}}$ \\
\hline 'foot, leg' & 'at the feet' & & 'on the feet' & & 'with/by the feet' \\
\hline yå & & y:ِّ̃ & yạaà & & yạֵa \\
\hline 'eye' & & 'in the eyes' & 'on the eye' & & 'before the eyes of \\
\hline kó & & kőő & kwáñ & & kwn̈n̈ \\
\hline 'each other' & & 'in each other' & 'together' & & 'together' \\
\hline kö & & & kwèy̆, kwèz & köว̈ & k̄̄̄ \\
\hline 'hand' & & & 'in the hands of' & 'on the hands of' & 'with a hand' \\
\hline zịāāà & & & & zịạàa zī̄āāa tä & \\
\hline 'road' & & & & 'at the road, on the road' & \\
\hline
\end{tabular}

ORIGIN: The declination of "locative nouns" in Dan-Gwectaa stems from a fusion of noun stems with postpositions. The tonal contrasts among the case forms reflect the original lexical tones of the postpositions. So, the non-low tone of the comitative case can be explained through the high tone of the comitative postposition $k a$, and the extralow tone of the subessive case is inherited from the subessive postposition bä. For more details, see (Vydrin 2011).

\section{Concluding remarks}

Although both languages belong to one mid-range family, the tonal systems of Bamana and Dan-Gwectaa seem totally different, cf. table 5. 
Table 5. Comparison of characteristics of the tonal systems of Bamana and Dan-Gwectaa

\begin{tabular}{lll}
\hline & Bamana & Dan-Gwectaa \\
\hline Number of tones & 2 & $5(+3$ modulated $)$ \\
Downdrift \& downstep & + & - \\
Contextual changes of tones & very much & minimal \\
Max. size of tonal domain & Unlimited (a tonally compact unit) & syllable \\
Number of tonal inflections & 1 & numerous \\
Character of realizations of & downstep \& contextual & substitution of the lexical tone \\
tonal inflections & modifications to the right & \\
\hline
\end{tabular}

There are two factors that can explain this divergence. The first one is just the time distance: as is proved by the history of better documented languages (especially those of East Asia), 4000 years (and even less) of independent evolution is quite enough to let tonal systems transform radically. The second factor is the areal influence: among all South Mande languages, Dan seems to be the most influenced by Kru languages whose typical characteristics are the polytony and multiple grammatical tones (Bearth et Link 1980; Vydrin 2009b). Bamana (and other languages of the Manding group), to the contrary, has a long history of contacts with non-tonal languages (Pulaar-Fulfulde, Wolof) or two-tone languages which tend to evolve towards accent-like systems. This environment was less conductive to the complication of its tonal system and grows of the functional load of tones. However, this tendency by itself does not exclude retention or emergence of tonal inflections: Bamana rather represents an extreme case, a language where the presence of tonal inflections is minimized, while in other two-level tonal languages of the Mande family it may be more prominent.

\section{Acknowledgments}

This work is supported by a public grant overseen by the French National Research Agency (ANR) as part of the "Investissements d'Avenir" program (reference: ANR-10-LABX-0083)". I would like to thank Nina Sumbatova for her insightful remarks and advices which helped very much to improve this text.

Abbreviations: ART - definite/referential article (floating low tone); CMM - common case; COM - comitative case; COP - copula; EMPH - tonal marker of the emphatic definite form; EXCL - excusive; EXI - existential pronominal predicative markers; FOC - focalization particle; $\mathrm{H}$ - high tone; INCL - inclusive; INF - infinitive tonal inflection; intens. intensive; IPFV - imperfective; IZF - izaphet tonal inflection; JNT - conjoint pronominal predicative markers; conjoint tonal inflection; L - low tone; LOC - locative case; $\mathrm{M}$ - mid tone; NEG - negative; NEUT - neutal aspect tonal inflection; NMLZ - nominalization; NONVIS - non-visual (non-firsthand); NP - noun phrase; NSBJ - non-subjective pronominal set; PFV - Perfective; PL - plural; PP - postposition; PRESTV - presentative; PRF - perfect; PRH - prohibitive; PROSP - prospective; REFL - reflexive pronoun; REL - relativization marker; SG - singular; SUB - subessive case; supint. - superintensive; TR - transitive

\section{References}

Bearth, Thomas, et Christa Link. 1980. "The tone puzzle of Wobe". Studies in African Linguistics 11(2): 147-207.

Bird, Charles. 1966. Aspects of Bambara Syntax. University of California. Los Angeles. 
Courtenay, Karen. 1974. "On the Nature of the Bambara Tone System". Studies in African Linguistics 5(3): 303-323.

Creissels, Denis. 1988. Le système tonal du bambara standard. Centre de Linguistique africaine de l'Université de Grenoble. Vol. 1. Etudes Manding. Grenoble.

—. 2009. Le malinké de Kita. Rüdiger Köppe Verlag. Vol. 9. Mande languages and linguistics. Köln.

Creissels, Denis and Claire Grégoire. 1993. "La notion de ton marqué dans l'analyse d'une opposition tonale binaire: Le cas du mandingue". Journal of African Languages and Linguistics 14 (2): 107-154.

Creissels, Denis and Pierre Sambou. 2013. Le mandinka. Phonologie, grammaire, textes. Karthala. Paris.

Dumestre, Gérard. 1987. Le bambara du Mali : Essai de description linguistique. INALCO. Paris.

Green, Christopher R. 2010. "Prosodic Phonology in Bamana(Bambara): Syllable Complexity, Metrical Structure, and Tone. Doctoral Dissertation". Bloomington: Indiana University.

Green, Christopher R. and Jonathan Anderson and Samuel Obeng. 2013. "Internal tonal processes in Susu". Mandenkan 50: 61-84.

Hulst, Harry, van der. 2012. "Deconstructing stress". Lingua 122: 1494-1521.

Khachaturyan, Maria. 2014. "Grammaire de la langue mano (mandé sud) dans une perspective typologique". PhD Thesis at the INALCO, Paris.

Leben, William R. 2003. "Tonal Feet as Tonal Domains". In Linguistic Typology and Representation of African Languages, Africa World Press, 5: 129-138. Trends in African Linguistics. Trenton: John Mugane.

Odden, David. 1996. “Tone: African Languages”. In John Goldsmith (ed.), The Handbook of Phonological Theory, Blackwell Publishing.

Vydrin, Valentin. 2009a. "On the problem of the Proto-Mande homeland." Journal of language relationship, 1: 107-142.

- 2009b. "Areal Features in South Mande and Kru Languages". In Norbert Cyffer, Georg Ziegelmeyer (eds.), When Languages Meet: Language Contact and Change in West Africa, 91-116. Köln: Rüdiger Köppe Verlag.

—. 2010a. "Le pied métrique dans les langues mandé". In Essais de typologie et de linguistique générale. Mélanges offerts à Denis Creissels, 53-62. ENS Éditions. http://halshs.archives-ouvertes.fr/halshs-00715537.

_. 2010b. "L"“aspect neutre" en dan-goueta et 1'Aktionsart". Voprosy Jazykoznanija, n 5: 87-101.

- 2011. "Déclinaison nominale en dan-gwèètaa (groupe mandé-sud, Côte-d'Ivoire)". Faits de langues: Les Cahiers 3: 233-258.

- 2012. “Аспектуальные системы южных манде в диахронической перспективе”. Acta Linguistica Petropolitana. Tpуды Института лингвистических исследований 8 (2): 566-647.

Vydrine, Valentin. 2004. "Areal and genetic features in West Mande and South Mande phonology: In what sense did Mande languages evolve?" Journal of West African Languages 30 (2): 113-125.

Weidmann, Scott and Sharon Rose. 2006. "A Foot-Based Reanalysis of Edge-in Tonal Phenomena in Bambara". In Donald Baumer, David Montero, Michael Scanlon (eds), Proceedings of the 25th West Coast Conference on Formal Linguistics, 426-434. Somerville, MA. 
Welmers, William. 1949. "Tonemes and Tone Writing in Maninka". Studies in Linguistics 7 (1): $1-17$.

Yip, Moira. 2007. “Tone”. In Paul de Lancy (ed.), The Cambridge Handbook on Phonology, 229-251. Cambridge: Cambridge University Press

Давыдов, А.В. 2011. “Заметки о диалекте бамана деревни Боре”. In Е. В. Перехвальская, А. Ю. Желтов, Le monde mandé: K 50-летию В. Ф. Bыдрина. Материаль экспедиции в Западную Африку (2001-...), 100-109. СанктПетербург: Нестор-История.

Макеева, Н.В. 2012. "Грамматический строй языка кла-дан в типологическом контексте родственных языков. Кандидатская диссертация”. 